DOI https://doi.org/10.18551/rjoas.2018-02.29

\title{
STUDY ON THE ABUNDANCE OF HETEROTROF BACTERIA ON LEAF LITTER MANGROVE IN COAST AREA SEDATI-SIDOARJO OF EAST JAVA
}

\author{
Nurmalita Dewi ${ }^{*}$ \\ Biotechnology Fisheries and Marine, Airlangga University, Indonesia
}

Nasuki, Rumayasa IGP Gede, Suseno Adi

Technology Aquaculture Program, Polytechnic Marine and Fisheries, Indonesia

*E-mail: dnesmoer@gmail.com

\begin{abstract}
Heterotrophic bacteria are responsible for degrading and recycling important elements such as carbon, nitrogen and phosphorus. Decomposers bacteria in mangroves litter, its existence has not been so much studied. Paper presents the results of study of the amount or abundance of rotting bacteria in the Avicennia marina, Sonneratia sp. and Rizopora apiculata on the coast of Sedati-Sidoarjo of East Java. Research method is experimental with field scale using Randomized Block Design or Randomized Complete Block Design by dividing the research for three blocks area, and statistics analysis with ANOVA. These results show that nearly $70 \%$ of mangroves in this area have been exposed or damaged. This is caused by human activities such as logging, opening of ponds and exposure of waves. The result of measurement of water quality parameter in this research ranged for $\mathrm{pH} 5.5-7.3$, salinity 2835 , brightness $25-50 \mathrm{~cm}$. Soil quality parameters are nitrite $0.143 \mathrm{mg} / \mathrm{L}$, phosphate 0.160 $\mathrm{mg} / \mathrm{L}$, ammonia $2.05 \mathrm{mg} / \mathrm{L}, \mathrm{COD} 80 \mathrm{mg} / \mathrm{L}$ and BOD $34 \mathrm{mg} / \mathrm{L}$. Litter weight are 230.97 $\mathrm{g} / \mathrm{m} 2 /$ year or 2.3 ton/ha/year in which leaf litter is the largest component of other organic waste. Waste production in this area is low compared to the result of Nurhasanah (1998) which reported 2.75 ton/ha/year. Statistics analysis with ANOVA showed significant difference between mangroves $(p=0,000)$.
\end{abstract}

\section{KEY WORDS}

Hetrotrof bacteria, mangrove, Avicennia maria, Sonneratia sp., Rhizopora apiculata.

One of the benefits of the existence of mangrove forests is to provide some food and nutrients for some marine animal species including those that have important ecosystem meaning. Nutrients and large amounts of organic matter in these mangrove forests are mostly derived from the leaves of mangroves and organisms that have died and broken down by microorganisms. Mangrove forests play a unique role and can not be replaced by forests and other ecosystems, namely as a chain of nutrients that are essential for several aquatic organisms (Hogarth, 2016). The vegetation has a certain composition and a clear zonation with uniform tree height.

In general, mangrove forests are known to have high productivity and many support the external ecosystem. Two important things that are interconnected are the material cycles within the forest and forest productivity. The material cycle includes importing and exporting organic materials that are still present or out of ecosystems spurred by existing physical and biological conditions (Willemsen, et al., 2016).

States that the litter of mangrove leaves in estuary provides an important nutrient base for the food web and is also an important food of fish and invertebrates. Although nutrient is poor when falling from trees, mangrove leaves become nutrients due to microbial processes (Naidoo, 2016).

The most important contribution of mangrove forests to aquatic ecosystems is through the decay of fallen leaves falling into the water. This leaves mangrove leaves an important source of organic material in the food chain in aquatic environments that can reach 7 to 8 
tons / ha / year. The fertility of the waters around the key mangrove area lies in the input of organic material derived from this leaf blossom (Nontji, 1993).

States that bacteria exist almost in all ecosystems on the earth where it is responsible for degrading and recycling essential elements or elements such as carbon, nitrogen and phosphorus (Alongi, 1994). The energy contained in the body of bacteria is actually larger than the energy contained in the body of living organisms so that bacteria can regulate the food chain system in the waters and inland.

The existence of bacteria in the mangrove forest area has a very important meaning in decomposing the leaves of mangrove into an organic element that is very important in the provision of food for the organisms that inhabit this mangrove forest, where according to Sikong (1978), the mass of bacteria and fungi together results decomposition into Food for detritus-eating organisms that mostly consist of invertebrate animals. This detritus-eating organism will in turn be eaten by fish and other crustaceans.

Bacterial decomposers and mangroves (litter), its existence has not been so much studied. A good understanding of the existence of this bacteria decomposers is an exploratory matter to find / find the functions and benefits, so it can be an important information in the management of ponds cultivation that is located in the vicinity of mangrove forest.

\section{MATERIALS AND METHODS OF RESEARCH}

This research was conducted on the field scale that is in the sediment area along in coast area Sedati-Sidoarjo. Water quality analysis was conducted in-situ while soil analysis and bacterial abundance were conducted in the Biology and Environment Laboratory of Polytechnic Marine and Fisheries at Sidoarjo and University Airlangga.

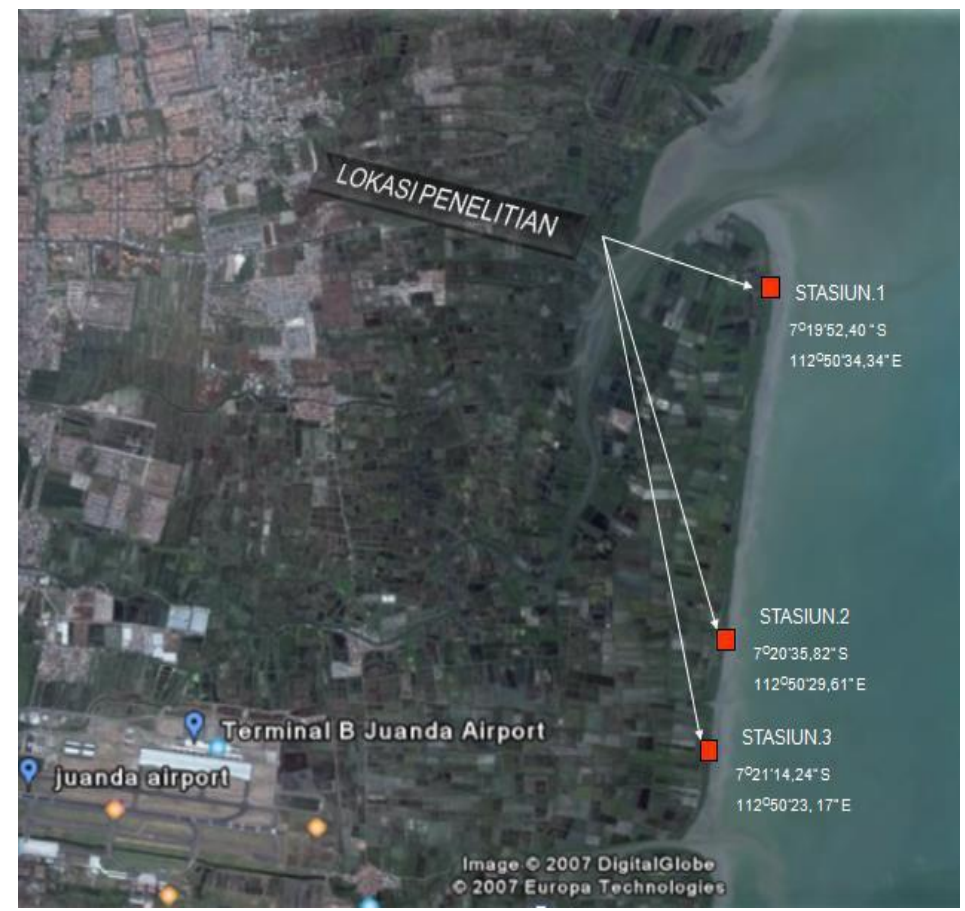

Figure 1 - Research Area

Determination research area bloc 1, 2 and 3, took a sample in field and brought to laboratory were sampled is decomposed leaves $(n=20)$. The method used is experimental with field scale using Randomized Block Design (RBD) or Randomized Complete Block Design (RCBD) by dividing the research area into 3 blocks. Each block consists of 3 treatments Avicennia marina, Sonneratia sp and Rhizopora apicuata with 3 replications for each type of mangrove. 
The mangrove leaves taken as samples are decomposed leaves that form the litter and are separated from the newly fallen. Test on litter production is done in-situ while to calculate the amount of bacteria found in leaf litter is done in laboratory bio-ling.

Statistics analysis showed significant different between kind of mangrove $(p=0,000)$ and to identify statistically significant variance, we used one-way analysis of variance (ANOVA) were performed using SPSS (Statistical Product and Service Solution) software.

\section{RESULTS OF STUDY}

Condition Mangrove. The mangrove forest that became the object of research in Sedati Sub-district of Sidoarjo Regency is located at $101^{\circ} 20^{\prime} 06$ " - 101 ${ }^{\circ} 24^{\prime} 10$ " BT and $1^{\circ} 35^{\prime}$ '25' '$1^{\circ} 37^{\prime} 30^{\prime}$ 'LU. The research location extends along $10 \mathrm{~km}$ with a thickness of $30 \mathrm{~m}$ in the northern part of which is limited by Buntung river and south there is Sungai Temak Cemandi which part of its condition is relatively good, whereas some or almost $70 \%$ have been opened or damaged (Fig.2 and Fig.3).
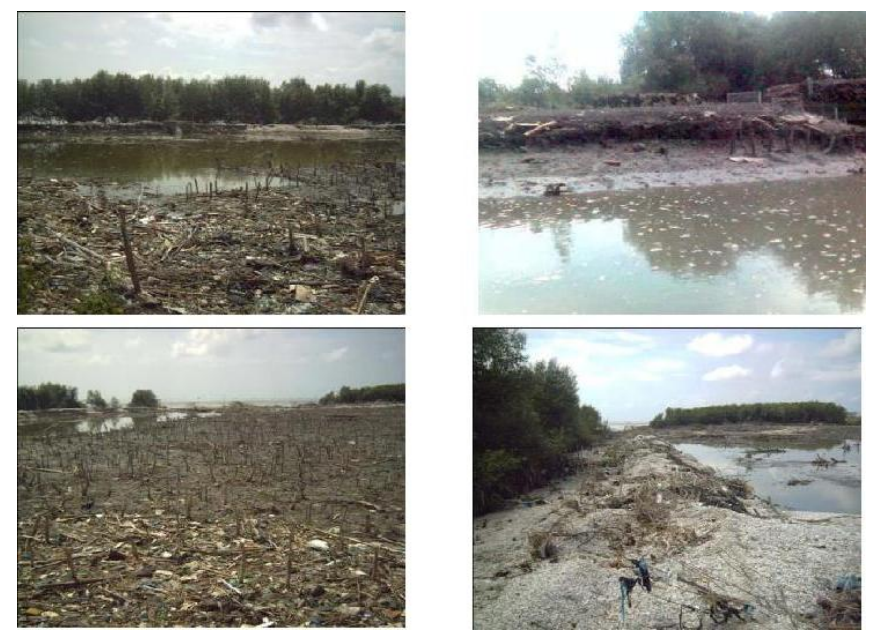

Figure 2 - Damage to mangroves in coastal area Ds. Segorotambak
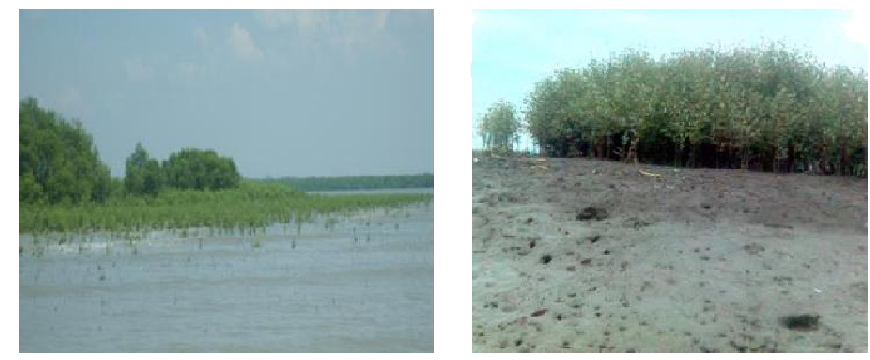

Figure 3 - The mangrove plant that grows in the sediment of the Buntung River estuary

Willemsen et al. (2016) showed the results indicated that a reduced sediment supply did significantly reduce the sediment trapping capacity of the mangroves. Enabling tidal exchange across the causeway, increasing the sediment supply to the mangroves, resulted in deposition rates increasing with up to $300 \%$. These results showed that re-establishing the sediment supply enhanced the resilience of the mangrove as higher deposition.

Water quality. Water quality parameters measured in this study is $\mathrm{pH}$ ranging from 5.5 to 7.3; Salinity 28 to 35 ; And brightness $25 \mathrm{~cm}$ to $50 \mathrm{~cm}$. While the soil quality parameters measured were Nitrite $0.143 \mathrm{mg} / \mathrm{I}, \mathrm{P} 0.160 \mathrm{mg} / \mathrm{I}$, total ammonia $2.05 \mathrm{mg} / \mathrm{I}$, COD $80 \mathrm{mg} / \mathrm{I}$ and BOD $34 \mathrm{mg} / \mathrm{I}$. In the study [7] ph ranged from 6.63 to 5.83 , while the salinity obtained tends to be lower than the conditions obtained in Indonesia. This is possible due to differences in the condition of the territorial waters. 
Serasah Production. The result of the measurement of the weight of the litter is $230.97 \mathrm{~g} / \mathrm{m} 2$ / year or 2.3 tons / ha / year in which leaf litter is the largest component of other organic litter (Fig.4). In several studies have been published on root decomposition. Litter decomposition is performed mainly by bacteria and fungi and initially fast, followed by the rate of decline. Nutrient concentration Such as nitrogen, phosphorus, potassium, magnesium and calciumdecline during decomposition The concentration of nitrogen, however, then increased due to colonization of detritus by bacteria, mushrooms, cyanobacteria and diatoms (Steinke, 1999). In many mangroves Standing, crabs and gastropods are able to remove it $30 \%$ of waste from the sediment surface (Lee, 2008). In Mngazana Muara, waste production is higher in summer than ininterinter, While leaf litter on the forest floor is minimal due to tides Rinsing and consumption by crabs. In this study $43 \%$ of waste is consumed.

With crabs, $10 \%$ decomposes on the forest floor and the rest $47 \%$ are exported (Rajkaran \& Adams, 2007).
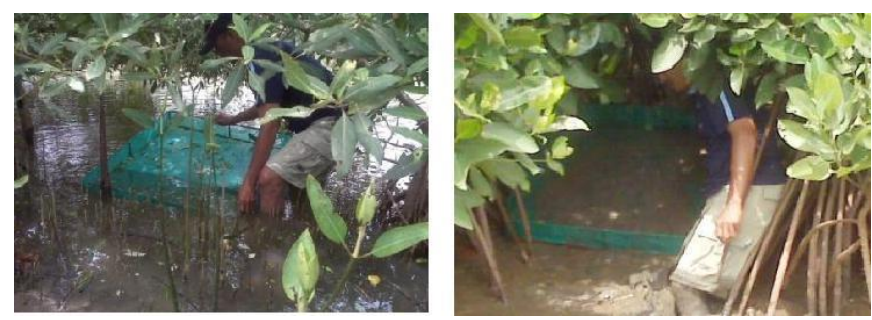

Figure 4 - Installation of mosaic litter traps Avicennia sp. and Rhizopora sp.

Total Bacteria. The average value of bacterial counts contained in the mangrove leaf litter as follows Sonneratia sp $1.077 \times 10^{8}$, Rhizopora sp $0.446 \times 10^{8}$, Avicennia sp 1,613 $\times$ $10^{8}$ (Fig.5).

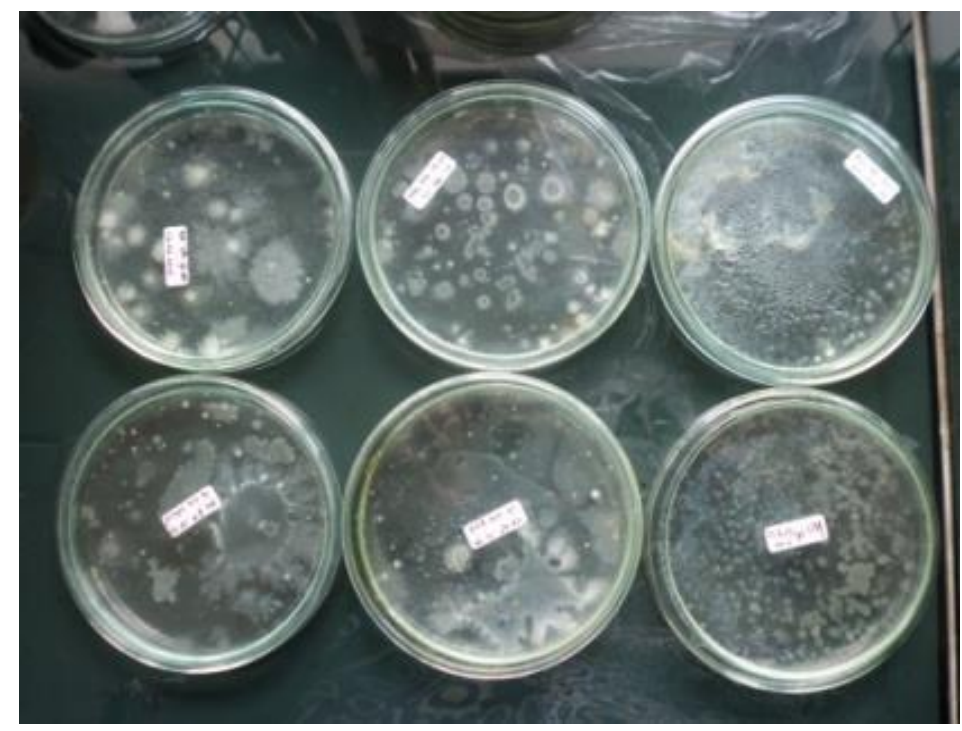

Figure 5 - Observation of bacterial count (TPC)

Analysis data. The result of BNT test with Tukey High Significant Difference method showed that the highest bacterial abundance was found in avicennia sp leaf litter. F and HSD test results can be seen in the following table (Table 1 and 2).

Table $1-F$ test results on the number of bacteria in three types of mangroves

\begin{tabular}{|c|c|c|c|c|c|}
\hline $\mathrm{n} / \mathrm{n}$ & Sum of Squares & $\mathrm{df}$ & Mean Square & $\mathrm{F}$ & Sig. \\
\hline Between Groups & 2.046 & 2 & 1.023 & 67.451 & .000 \\
\hline Within Groups & .091 & 6 & .015 & - & - \\
\hline Total & 2.137 & 8 & - & - & - \\
\hline
\end{tabular}


Table 2 - HSD test results on the number of bacteria in three types of mangroves

\begin{tabular}{|c|c|c|c|c|}
\hline \multirow{2}{*}{ Species } & \multirow{2}{*}{$\mathrm{N}$} & \multicolumn{3}{|c|}{ Subset for alpha $=.05$} \\
\cline { 3 - 5 } & & 1 & 2 & 3 \\
\hline Rhizopora sp & 3 & .4467 & & \\
\hline Sonneratia sp & 3 & & 1.0767 & 1.6133 \\
\hline Avicenia sp & 3 & & & 1.000 \\
\hline Sig. & & 1.000 & 1.000 & \\
\hline
\end{tabular}

\section{DISCUSSION OF RESULTS}

Mangroves are highly productive coastal ecosystems found within the intertidal zones of the tropics and subtropics ranging from $35^{\circ} \mathrm{N}$ to $40^{\circ} \mathrm{S}$ latitude (Giri, et al., 2011). Damage occurring in some coastal areas caused by human activities in the form of logging, pond opening and exposed to wave hempasan. Scattered forests are found in several places and also found in ponds. Vegetation of mangrove forests in this area is generally small in size, both in diameter and height of trees are low. This condition is due to mangrove plants along the coastline Sedati District is relatively new or young growing vegetation as a result of the formation of new land due to the results of mud sediments carried by the river. Sampling was conducted on three groups of mangrove species with the distribution of location based on the representation of the species. The mangrove leaves taken as samples are decomposed leaves that form the litter and are separated from the newly fallen daunyang. Test on litter production was done in-situ while to calculate the amount of bacteria found in leaf litter was done in bio-ling laboratory of Sidoarjo Fishery Academy and University Airlangga. Nutrient availability inmangrove ecosystems is generally low, being influenced by tides, soil redox potential, organic matter content, microbial activity, soil type and surface elevation (Reef, et al., 2010). Nutrient deficiency in mangroves is due to the infertility of upland soils and low terrigenous input, and is indicated by slow growth rates, high root/shoot ratios, sclerophylly and nutrient resorption from senescent tissues (Reef, et al., 2010). Besides testing the above parameters, measurement of water quality parameters as supporting parameters for data analysis.

Measurement of litter production is aimed to determine the size of litter produced by one forest area in one year. Litter production in this area is low compared to Naidoo (2016) which reported 2,75 ton / ha / year. This condition is suspected because the mangrove forest in the coastal area of Sidoarjo Regency is a vegetation that is classified as young or growing new. The mangrove leaves that became the object of the study were limited to three species of mangroves namely Sonneratia spp, Rhizopora apikulata and Avicennia marina in the form of leaf litter (mangrove leaves that rot). Low litter production indicates that the area is relatively small in providing organic materials as a source of nutrients for detritus but the abundance of bacteria is quite high, presumably because the availability of nutrients is supplied from sediments formed from the river flow so that potential for the development of fish seeds as well other types.

\section{CONCLUSION}

Vegetation of mangroves in coast Sedati-Sidoarjo is dominated by Avicennia sp with low litter production of 2.3 ton / ha / year but high bacterial abundance is $1,04 \times 10^{8}$.

\section{ACKNOWLEDGEMENTS}

This work was partially supported by Polytechnic of Maritime and Fishery Sidoarjo in cooperation with Airlangga University. This research was done financially supported by research fund of Poltek Kp Sidoarjo. The authors are very grateful to field staff and laboratory staff who have supported our research data. Sincere thanks to anonymous privacy for their help. Critical comments and suggestions are important for improving the manuscript. 


\section{REFERENCES}

1. Hogarth J.P. 2016. Mangrove system. Reference module in life sciences. UK.

2. Willemsen M.J.W.P, Horstman M.E, Borsje W.B, Friess A.D, Dohmen-Janssen M.C. 2016.Sensitivity of the sediment trapping capacity of an estuarine mangrove forest. 273: 189-201.Netherland.

3. Naidoo G. 2016. The Mangroves of South Africa: an ecophysiological review. South African Journal of Botany 107 (2016) 101-113. South Africa.

4. Nontji.A. 1993. Laut Nusantara. Djambatan. 368.Jakarta.

5. Alongi D.M. 1994. The role of bacteria in nutrient Recycling in tropical mangrove and other Coastal Benthic ecosystem. Hydrobiology 285: 19-32.

6. Sikong M. 1978. Peranan Hutan Mangrove sebagai tempat Asuhan berbagai jenis ikan dan Crustacea. Dalam prosiding seminar ekosistem mangrove. 106 - 108. Jakarta.

7. Peng Y, Diao J, Zheng M, Guan D, Zhang R, Chen G, Lee Y,S. 2016. Early growth adaptability of four mangrove species under the canopy of an introduced mangrove plantation: implications for restoration

8. Steinke, T.D., 1999. Mangroves in South African Estuaries. In: Allanson, B.R., Baird, D. (Eds.), Estuaries of South Africa. Cambridge University Press, Cambridge, United Kingdom, pp. 119-140.

9. Lee, S.Y., 2008. Mangrove macrobenthos: assemblages, services, and linkages. Journal of Sea Research 59, 16-29.

10. Rajkaran, A., Adams, J.B., 2007. Mangrove litter production and organic carbon pools in the Mngazana estuary, South Africa. African Journal of Aquatic Science 32, 17-25.

11. Giri, C., Ochieng, E., Tieszen, L.L., Zhu, Z., Singh, A., Loveland, T., Masek, J., Duke, N., $2011 \mathrm{~b}$. Status and distribution of mangrove forests of the world using earth observation satellite data. Glob. Ecol. Biogeogr. 20, 154-159.

12. Reef, R., Feller, I.C., Lovelock, C.E., 2010. Nutrition in mangroves. Tree Physiology 30, 1148-1160. 